\title{
Vibrio vulnificus
}

National Cancer Institute

\section{Source}

National Cancer Institute. Vibrio vulnificus. NCI Thesaurus. Code C86847.

A species of facultatively anaerobic, Gram negative, curved rod shaped bacteria assigned to the phylum Proteobacteria. This species is motile, oxidase positive, hemolytic,

halophilic, and can produce acid from arbutin but not from sucrose. $V$. vulnificus is a

marine org anism and a pathogen that causes wound infections and septicemia and has a higher rate of mortality than infections caused by other Vibrio species. 